\title{
May-Hegglin Anomaly
}

National Cancer Institute

\section{Source}

National Cancer Institute. May-Hegglin Anomaly. NCI Thesaurus. Code C131646.

An autosomal dominant disorder characterized by the triad of thrombocytopenia, giant

platelets, and characteristic inclusions in peripheral blood leukocytes. It is characterized by varying degrees of thrombocytopenia that may be associated with purpura and bleeding; it is associated with mutation of the MYH9 gene. 